\title{
Classroom Management of Senior and Yunior English Teachers in Medan
}

\section{Masitowarni Siregar}

Universitas Negeri Medan, Indonesia

Email: siregramasitowarni@yahoo.com

\begin{abstract}
:
The purpose of the study was to find out the differences between the classroom management performed by the senior and yunior teachers in teaching English at senior High School in Medan. This is a descriptive qualitative study. The respondents of the research were 28 English teachers of Yunior and Senior High School in Medan. Questionnaire and Observation sheet were used to collect the data on the teachers classroom management. The result of the study shows that senior English teachers perform more aspects of Classroom management. They perform 18 point from 20 points aspect.. Junior English teacher get 17 point. Although senior teachers perfom only show slightly more aspect of classromm management but for the quality of classroom management they perform better due to the longer experience of teaching. For junior English teacher they perform more enthusiastics energy, although it is clear that they have to study more on the behavior and attitude expected in the classrooms.
\end{abstract}

\section{Keywords:}

classroom management; English teacher

\section{Introduction}

Classroom Management in the context of teaching and learning is defined as the type of activity carried out by the teacher to create and maintain optimal conditions for teaching students. The various activities created in a manner so that the teaching and learning process can take place properly. Classroom management is a method used to organize classroom activities, instruction, physical structure and other features to make effective use of time, to create a happy and productive learning environment, and to minimize behavior problems and other disruptions.

Effective classroom management will create an optimal teaching and learning process. There are some differences in thinking about the best way to manage classes. These differences include: the old view emphasizes the creation and application of rules to control student behavior while the new view focuses on students' needs to develop relationships and opportunities to organize themselves.

Learning is a change in behavior due to the interaction of individuals with the surrounding environment. While teaching is any deliberate effort in order to give possibilities for students to occur in the learning process in accordance with the goals that have been formulated. Therefore class management is one of the abilities that a teacher must have in managing a class.

Old views that orient students to passivity and obedience to strict rules can weaken student involvement in active learning, thinking, and construction of social knowledge while new views in classroom management place more emphasis on guiding students to become more self-disciplined and less stressed on control external to the student. In the old view the 


\section{Britain International of Humanities and Social Sciences (BIoHS) Journal \\ ISSN: 2685-3868(Online), 2685-1989(Print) \\ Vol. 2, No. 2, June 2020, Page: 623-631}

teacher is considered as a regulator while in the new view the teacher is considered as a guide, coordinator and facilitator. Therefore this study aims at finding out the differences of classroom management performed by senior English teacher and yunior English teacher.

\section{Review of Literatures}

\subsection{Nature of Classroom Management}

There are several opinions or definitions put forward by experts about classroom management. Nawawi, H. (1999: 116) and Arikunto, S (1999-17) agree that classroom management is an effort carried out by the person in charge of teaching and learning activities or who helps with the intention of achieving optimal conditions so that learning activities can be carried out as expected. Amentembun (1998: 3) defines Classroom management as the management of the class that is the leadership or management of the teacher in organizing the class. This includes activities that create and maintain optimal conditions for effective learning.

This means that classroom management or management activities can be interpreted as the ability of the teacher or homeroom teacher in carrying out the class potential in the form of providing the widest opportunity for each person to carry out creative and directed activities so that the available time and funds can be used efficiently to carry out activities. Class activities related to the curriculum and student development.

Class management is an effort carried out by the person in charge of teaching and learning activities or that helps with the intention to achieve the conditions of learning activities as expected. Class management skills are the ability of teachers to create and maintain an optimal teaching and learning atmosphere. This ability is closely related to the ability of teachers to create favorable conditions, delight students and create healthy learning disciplines.

Class management shows activities that indicate activities that create and maintain optimal conditions for the learning process. Class management must be addressed with management corrective actions. As a basis for providing and preparing conditions for an effective learning process, classroom management refers to the arrangement of people (in this case, especially students) and the arrangement of facilities. Facilities here include a broad understanding ranging from ventilation, lighting, seating to planning appropriate teaching and learning programs. Of

Class management broadly are divided into two categories:

1. Physical management, namely the management and arrangement of classrooms that support the occurrence of teaching and learning processes effectively and efficiently. Such as: air travel arrangements, lighting arrangements, student seats, teacher's desk chairs, blackboards, learning tools, and so on.

2. Management that includes students, namely efforts to create and maintain student motivation to consciously participate and be seen in the process of education and teaching in schools. The effort is manifested in the form of activities, behavior or atmosphere that is regulated or spoken by the teacher by stimulating and opposing students in full, good classroom management will drive the process of teaching and learning interactions that are good too. 


\subsection{Teacher Functions in Class Management}

Aembembun, N.A (1998) explains that the function of the teacher in the practice of classroom administration includes:

\section{a. Instructional Function}

Instructional Function function to carry out teaching tasks (to teach), this task is a teacher's traditional task. The teacher's instructional functions include:

1. Convey a number of cultural knowledge, and facts to students.

2. Provide assignments for students.

3. Correcting or checking students' assignments and work and giving grades or scores.

This instructional function by almost all teachers is always prioritized and is still dominant in the career of most teachers in Indonesia.

\section{b. Educational function}

This educational function for teachers is actually a basic function of the function to educate, because teachers not only carry out teaching tasks but also educate. Even this function of educating must take precedence and must be the central function of the teacher. With its educational function, a teacher not only tries to make his students smart but he will try to make his students become adults with good personalities.

\section{c. Managerial Function}

In addition to the teacher having instructional and educational functions, the teacher also has a task or managerial function that is able and able to lead the class.

\subsection{The objectives of Class Management}

a. Creating classroom situations and conditions that enable students to develop their abilities optimally.

b. Maintaining a stable state in the classroom atmosphere, so that if there is a disruption in learning can be eliminated.

c. Remove obstacles and violations of discipline that can hinder the realization of teaching and learning.

d. Organize all equipment and equipment that allows students to learn in accordance with the social, emotional, and intellectual environment of students in the classroom.

e. Serve and guide individual differences in students.

\subsection{Principles of Class Management}

a. Warmth and enthusiasm

b. Challenge, use words, actions or material with a challenging presentation

c. Vary, use variations in the teaching and learning process

d. Flexibility is used when teachers get into obstacles in student behavior so that teachers can change their teaching strategies

e. Emphasize positive things, maintain positive things and avoid concentration.

\subsection{Components of Classroom Management}

There are two main components regarding classroom management skills that teachers need to pay attention to, namely:

a. Preventive skills, namely skills to create and maintain optimal learning conditions in order to avoid unfavorable situations or damage the teaching and learning process.

b. Skills that are repressive, namely skills that return conditions of teaching and learning that do not determine the conditions of teaching and learning that do not determine the conditions of effective learning. 
In developing preventive skills, teachers can use their abilities by:

a. Showing responsiveness. In his teaching assignment. The teacher must be physically and mentally involved in the sense that the teacher always has time for all student behavior, both students who show positive behavior and negative behavior.

b. Divide attention. The teacher must be able to share the attention of all students. That attention can be visual or verbal.

c. Focus group attention. Introduce and increase the involvement of students by focusing the group on their tasks from time to time. This activity can be done by always alerting students and demanding students' responsibility for their tasks.

d. Give clear instructions. This guide can be done for the material delivered, assignments given and other student behaviors that relate directly or indirectly to the lesson.

e. Rebuke. Reprimand students if they exhibit disruptive or distorted behavior. Convey the admonition firmly and clearly on disturbing behavior, avoiding rude and hurtful taunts and warnings.

f. Give reinforcement. Positive and negative behaviors of students need to be reinforced. Positive behavior is given reinforcement so that the behavior reappears. Negative behavior is given reinforcement by giving a reprimand or punishment so that the behavior does not happen again.

\subsection{Things that should be avoided}

Some things that should be avoided in developing classroom management skills are:

a. Excessive interference. If the teacher interferes too much with students, for example giving interruptions, questions, and sudden asssignments when students are busy doing the task, it will cause disturbed activities and students feel the teacher is too interfering.

b. Silence. When the teacher explains to students then the teacher suddenly stops him for a long time because of the possibility of the teacher forgetting or not mastering the material at all.

c. Inaccuracy in starting and ending activities d. Deviations. e. Wordy f. Repeat unnecessary explanations.

\subsection{Effective Classroom Management}

If the class is given a limit as a group of people who work together, who get instruction from the teacher then there are people who do learning activities with their characteristics that are different from one another.

In addition, class organization not only functions as a basis for the creation of teacher and student interaction but also adds to the creation of effectiveness, which is group interaction. From the research results it has been concluded that several problem variables need to be considered to create a healthy and effective classroom climate, as follows:

a. If the classroom situation allows children to learn optimally, group functions must be minimized.

b. Class management must provide facilities to develop unity and cooperation.

c. Group members must be given the opportunity to participate in decisions that affect relationships and conditions of study or work.

d. Group members must be guided in completing guidance, tension and feeling depressed.

e. It is necessary to create strong friendships and trust between students

\subsection{Strategy of Classroom Management}

Classroom management is one of the big problems of pre-service teachers (Merç \& Subași, 2015). Student-teacher must set the strategy to handle and solve the problem on 
classroom. Classroom management is basic to improve academic and behavioral outcomes to manage students ${ }^{\text {ee }}$ behavior disorders (Oliver, Wehby, \& Reschly 2011). Effective classroom management strategies can help pre-service teachers to create such an environment, ranging the activities to improve teacher-student to rules the regulate student behavior (Korpershoek, Harms, Boer, Kuijk, \& Doolaard, 2014). Effective classroom management may help teachers to teach students how to be responsible and control themselves (Gordon, 2001). So the students will be more responsible on their attitude.

According to Evertson and Weinstein (2006) there are five types of action to handle the classroom management. Teacher must develop caring, supportive relationships with and among students. Teacher must organize and implement instruction in ways that optimize students ${ }^{\text {ee }}$ access to learning. Teacher must encourage students ${ }^{c e}$ engagement in academic tasks, which can be done by using group management methods. For example is establishing rules and classroom procedure. The teachers also have to promote the development of students ${ }^{\text {ee }}$ social skills and selfregulation

\section{Research Methods}

This is a descriptive qualitative research. This study attempts to descrive the classroom management used by senior and yunior English teacher in Medan. 28 English teacher become the respondents of the study. 14 Teachers as Senor English teacher with the age of 45. Others are yunior English teacher with the age of betwee, 26 - 40. The instruments to collect data was questionnaire and observation.

\section{Discussion}

\subsection{Finding}

Based on the data from 14 senior English teachers and 14 yunior English teachers the followings are the description and discussion of the study. There are 20 aspects of the Classroom management in the questionnaire covering: 1.The interview consisted of 20 aspects: Arranging seats, 2.Positioning the teaching material 3.Lead the prayer4. Checking attendance 5.Arranging Learning constracts 6. Checking student's worksheet 7.Valuing students'opinion in verbal and nonverbal communication8. Appreciate students'opinion in verbal and nonverbal communication, 9. Helping students in solving problems (questions, tasks). 10 Evaluate students' work, 11. Give clear material, 12. Preparing learning media, 13.Motivating students to active learning, 14.Leading the discussion process, 15. Observing learning achievement,. 16. Collecting tasks on time, 17. Starting the class on time, 18 keep the class clean. 19. Ending the class on time .20. Correcting students with bad verbal communication

The followings are the data based on the questionnaire given to the students and based on the observation made in their classroom to confim their respond in the questionnaire.

1. Arranging seats

In arranging seats all teachers arrange the seats well, because the seats are already arranged in groups from the first day of semester. So all students were put in groups, for group work purpose. But some yunior teachers like to rearrange the seats although the group are still the same.

2. Positioning the teaching material

All the teachers used English book from the government.

3. Lead the prayer 
Leading the prayer becomes good habit in the classroom now. All mange to lead the prayer by asking the students to lead the prayer in turn.

4. Checking attendance

All senior and yunior teavhers always check students' attendance.

5. Arranging Learning contracts

All teachers; senior and yunior English teachers have developed the learning contracts together with othe English teacher in the school.

6. Checking students worksheet

Both senior and yunior English teachers claim that they check their students worksheet and give feedback to the worksheet.

7. Valuing students'opinion in verbal and nonverbal communication

Both senior and yunior teachers respect and value the opinios given by the students. They said that they always encourage the students to speak up and respect if the poins given correct or not correct.

8. Appreciate students'opinion in verbal and nonverbal communication

Both senior and yunior teachers give appreciation to students by using verbal and non verbal communication

9. Helping students in solving problems (questions, tasks)

All senior and yunior teachers help the students to solve their problems in form of givimg questions if they have problems and offering solution. Some other give proper tasks to overcome students problems. With these all students think they the teacher pay attention to them and in turn this will motivate the students to learn.

10. Evaluate students'work

All senior and yunior teachers claim that they evaluate their students work.

11. Give clear material

All senior and yunior teachers are in opinon that they give clear and appropriate material to the students because they have followed the materials in the book provided by the government. This aims at ease the students to understand the leassons.

12. Preparing learning media

All senior and yunior teachers claim that they have prepared the media before class. So they always used media in teaching, mostly they use laptop to teach. But, yunior teachers claim thay they use laptop and in focus to teach because they say they used videos and powerpoints to teach. In addition the young teachers also use cards to teach and use more variations of teaching media.

13. Motivating students to active learning

All senior and yunior teachers state that they always motivate the students to be active in the learning process by designing work that demand all students have to take part in the task given or to collaborate.

14. Leading the discussion process

All senior and yunior teachers argue that they always make discussion in the classroom to promote students' understanding and active learning.

15. Observing learning achievement

All senior and yunior English teacher claim that they observe the students learning achievement to find out if the students have been in the proper process in trying to achieve the competencies.

16. Collecting tasks on time

All senior and yunior English teacher claim that they try to collect the task on time, although a number of students often find reason not to collect the task on time.

17. Starting the class on time 
Starting the class on time is a must according to both senior and yunior English teacher. They said they always try to come on time and start the class on time to educate the students about discipline.

18. Keep the class clean

All senior and yunior teachers make sure that the class keep clean. They say that they always ask the students to check if their sourrounding clean or not. They make sure that there is rubbish bin in front of the class so that the students can easily throw the rubbish in the rubbish bin.

19. Ending the class on time

All senior and yunior teachers claim that they always end the class on time. If the bell rings they have to end the class because there will be another class follow. But 7 senior English teachers or $50 \%$ of senior teachers ussualyy prolonged the time for about 5-10 minutes due to giving clarification of students' misconception.

20. Correcting students with bad verbal communication.

All senior and yunior teachers claim that they always correct their students bad verbal communication. This is due to the proper or not properly speaking. If the teachers find out studens who do not communicate or speak politely or properly they always correct the students.

\subsection{Discusssion}

The results of the questionnaire and observations and analyses shows that the teachers have already successfully performed classroom management in teaching: learning activities, attitudes or responses, planning done before learning, and responsibilities, although some qualities seems to be more on the senior teachers performances of classroom management. The following discusses the differences qualities and consequences.

First in terms of chairs set up, the senior teachers set up the students chairs and tables before they start the learning process from the beginning of semester and seem never change. Junior English teachers reset up the students chairs and table formation before they start the learning process, although still in the form of group work but they set into difference position.

Second, Junior teacher is still having difficulties at arranging the lesson plan, it is because they still have not obtained comprehensive knowledge as a young teacher. And also their experience in teaching is still limited. But for the senior teacher who have already been professional at teaching in a long time and has broad knowledge of the they always arrange their own lesson plan and discuss with their colleagues.

Third, junior teacher almost never gave a warning to their students. It is because they still have not fully comprehend yet every students characteristic in the classroom.Sso it makes them a little bit afraid to make a warning to them. They afraid if their action would lead them to a complicated situations.

Fourth, based on observations it was found out that senior and junior teacher in the media they say they prepare of learning media. But based on observation, senior teachers just provided learning media like a laptop. On the other hand, the junior teachers do not only use the digital media but also use media non digital like card ect. Further, senior teachers shows their professionalism and have a lot of experience in the field of teaching and learning activities. With so much experience the teacher has various kinds of activities carried out in the classroom systematically.

Fifth the junior English teachers, for they still new in the world of education they usually do not have a clear picture of students' attitudes and the school cultures when they are 
exposed directly in the real world. On the other hand junior teachers seem to be more enthusiastic in organizing what strategies to make their students becomes more comfortable with their lessons.

Then the last is junior teacher seems to always finish their lesson on time. Unlike the senior teacher who sometimes finish the class with 5-10 minutes more longer than the schedule. It is because the senior would like to see clearly the result of their teaching process today. If the senior teachers found out problems they would put extra time to overcome the problems.

The senior and yunior teachers said that based on the questionnaire the teachers had the opportunity to evaluate their teaching performances. The perspective of the teacher is often different between senior and junior teachers. From the external and self-analysis teachers see that often deviations are present. Some teachers often have a better self-image about their teaching competences and see themselves as very good teachers. For example: The teachers are not aware that they did not give enough feedback and praise, that they do not have a positive classroom atmosphere and that they do not have a good way of handling mistakes. The teachers also acknolwledge that they do not recognize if there is no good classroom atmosphere that they do not give enough feedback and praise and that thay always critics the students for their mistakes. They recognize their weaknesses and know what factors contribute to good teaching. From the analyses of senior teachers are already very good in teaching the classroom. They recognize lacks in their teaching, although their classroom already effective and successful.

Teachers, yunior and senior do need knowledge of classroom management to teach successfully in different areas, for example: feedback and praise, handling mistakes, questions from students, and clearly structured lessons. Teachers also have to handle areas of reducing anxiety, motivation, humor and active time to learn are topics which are very important for teachers. Effective classroom management must be aligned with instructional goals and activities.

\section{Conclusion}

From the result of the study it can be concluded that : senior English teachers more aspects of Classroom management. They perform 18 point from 20 points aspect.. Junior English teacher get 17 point. Although senior teachers anly show slightly more aspect of classromm management but for the quality of classroom management they perform better due to the longer experience of teaching. For junior English teacher they perform more enthusiastics energy, although it is clear that they have to study more on the behavior and attitude expected in the classrooms.

Therefore some suggestions are offered. First, English teachers are suggested to be more aware of skills of classroom management. They are expected to always learn new insight on the development or the most current views of managing classrooms. Teacher also have to more creative in teaching the classroom, for example the teacher can provide interesting learning media so the students do not get bored in the learning.Head Second, of School are expected to suggest English teachers to explore more on the knowledge and the skills of managing classroom based on the recent research results. Third, English education Study program at Universities are suggested to up grade the Knowledge and Skills for Classroom Management taught in the Curriculum. They are suggested to strengthen and empower the candidate English teachers with powerful Classroom Management knowledge and skills. 
Last,other researcher are suggested to conduct a more in depth analysis and broader scale of research on classroom management.

\section{References}

Ahmadi,AbudanWidodoSupriono. PsikologiBelajar, Jakarta : PT RINEKA CIPTA,1991. Annisatul. (2009) Strategi Belajar Mengajar .Yogyakarta : Teras.

Arikunto Suharsimi. 1997. Pengelolahan Kelas dan Siswa : Sebuah Pendekatan Evaluatif .Jakarta: PT RajaGrafido Persada.

Ritu, Chandra 2015. Classroom Management for Effective Teaching. International Journal of Education and Psychological Research (IJEPR)

Djamarah, S. B.\& Zain, Aswan (1997), Strategi Belajar Mengajar. Jakarta : PT Rineka Cipta

Katharina, Sieberer \& Nagler. 2016. Effective Classroom-Management \& Positive Teaching. Austria : Canadian Center of Science and Education

Mu'awanah. StrategiPembelajaran, :Pedoman Guru danCalon Guru. Kediri : STAIN KEDIRI PRESS, 2011.

Mulyadi. Diagnosis ksulitan Belajar dan Bimbingan terhadap Kesulitan Belajar Khusus ,Yogyakarta : Nuha Litera,2008.

Rohani, Ahmad dan Abu Ahmadi. PengelolahanPengajaran. Jakarta : PT Rineka Cipta,1991.

Yildiz ,Guner Nevin. 2017. Classroom Management and Student Achievement : A Study on Five Elementary Classrooms. Turkey : AJESI - Anadolu Journal of Educational Sciences International. 